\title{
Civil Liability in Construction Contracts and Compensation Practices in Iranian Law with an Emphasis on British Law
}

\author{
Nancy Asbaghi Pour ${ }^{1} \&$ Mohammadreza Sharafatpeima ${ }^{2}$ \\ ${ }^{1}$ Department of Law, Bandar e Anzali International Branch, Islamic Azad University, Bandar e Anzali, Guilan, \\ Iran \\ ${ }^{2}$ Department of Private law, Bandar e Anzali Branch, Islamic Azad University, Bandar e Anzali, Iran \\ Correspondence: Mohammadreza Sharafatpeima, Department of Private law, Bandar e Anzali Branch, Islamic \\ Azad University, Bandar e Anzali, Iran.
}

Received: June 6, 2016 Accepted: June 27, 2016 Online Published: June 29, 2016

doi:10.5539/jpl.v9n5p283 URL: http://dx.doi.org/10.5539/jpl.v9n5p283

\begin{abstract}
The huge volume of construction activity in our country, is done in compliance with the Treaty and the general condition of Treaty. Although there is no legal requirement but even in private sector activities, these conditions are considered because total material of general conditions of Treaty is largely justifying the employer. Civil liability and contracts in construction contracts can help to a large extent. The subject of this study is to find an answer for the question which what is the basic difference between Iranian and British laws on compensation practices in construction contracts? And also what's the difference between compensation basic conditions in construction contracts in Iran and Britain law? In Iranian law, compensation practices in construction contracts is implementation of the same commitment in the first place and the compensation is in case that it is explicitly foreseen in the contract; while compensation is existed in the British legal system compensation practices in construction contracts; While compensation is existed in the British legal system compensation practices of construction contracts and there is not a concept as implementation of the same commitment as one of the compensation practices. Compensation may be stipulated in the contract in the Iran's law or customs or law requires compensation, in British law also, compensation does not require to be stipulated in the contract.
\end{abstract}

Keywords: construction contracts, contractual liability, civil liability, Iran's law, British law

\section{Introduction and the Subject Outline}

Full compensation and losses caused by the career errors in construction contracts would not be possible unless to be identified the tasks and duties that the legislator has predicted in particular for them in addition to exploring the scope of contractual duties and obligations of owners of professional careers because With the development of jobs professional responsibilities such as engineers, lawyers, doctors under the civil liability title or other professional job it is not possible to investigate contractual liability of them and to avoid more damages, it needs to investigate the individuals legal liability and enforcement carefully to not waste the right of the person and no losses remain uncompensated.

Construction contracts have been very important during human life especially in the recent years since human needs of housing and adequate shelter at different time was and is undeniable. Prevalence of this type of contract is common in the government agencies as well as between private parties, these contracts include a variety of consequences, including the obligations arising from these contracts.

The increasing complexity of manufacturing industry alongside the rapid development of the industry, have made inevitable frequent exposure to claims construction contracts. Some of the claims of construction projects are related to compensation, In general, wherever a person is forced to compensate other damages, it is said that he has civil liability. Responsibility of the person to compensate for damages caused by his actions is a natural rule... and based on this responsibility, special religious relationship is created between the injured and responsible one that injured, creditor and responsible one, the debtor and the debt issue are compensation.

By introducing what mentioned in this article, author is trying to extract methods of dispute resolution and compensation for construction projects in the mentioned countries law by careful investigating the principles and general rules governing the construction contracts in the law of Iran and Britain, and comparatively explain 
similarities and differences of each.

\section{Compensation Practices and Conditions in Construction Contracts in Iranian Law}

In this discussion, first, the elements of contractual liability in contract building is discussed and then compensation practices, compensation conditions, means of exemption from the payment of damages and ultimately civil liability of manufacturers in construction contracts in accordance with Iranian law.

\subsection{Components of Contractual Liability in Building Contract}

The existence of a valid contract between the employer and the contractor, breach of contract, damage due to breach of contract and the causal relationship between the breach of contract and damages are components of contractual liability in building contract which each can be investigated in separate sections.

\subsubsection{The Existence of a Valid Contract between the Employer and the Contractor}

Contractual liability of building contractor is created when the valid contact exists between employer and the contractor. As the essential condition of any deal stipulated by Article 191 of the Civil Code, intent and consent of the parties is an essential condition for conclusion of construction contracts. In construction contracts, what is considered as offer and acceptance is the parties reach an agreement on the nature of the contract, operation of matter of the contract and payment of operation of matter of the contract (Shahidi, 1331, p. 143).

\subsubsection{Breach of Building Contract}

The most important condition of contractual liability is breach of obligations under the contract. Basic commitment contract for the construction is the obligation to fulfill the commitment means to build building is the subject of the contract. For judging theories it must be said that According to the deniers need for fault in contractual liability, is not far from the material 222 and 229 of the Civil Code, Only proof of "commitment non-performance" is enough to make the obligee responsible for the damages and does not need to prove fault. Only by proving the fulfillment of the obligation or force majeure can committed person recover for exemption from contractual liability.

\subsubsection{Damage Due to Breach of Building Contract}

The purpose of contractual liability is compensation: Violation of performance of contractual obligations by itself does not establish liability and to committed be responsible to promisee, damages need to affect the promisee. In other words, damages should therefore arise as a result of breach of contract to responsibility be created to compensate it and debt be the responsibility of the responsible person. Thus, it can be noted that damage is the basic component of contractual liability. In Articles 515 and 521 of the Civil Procedure Law has been emphasized on the need to prove contract damage.

\subsubsection{Causal Relationship between the Breach of Contract and Creating Damage}

Proving damage as well as breach of contractor contract commitments alone does not justify the claim damage, Must be established that there is a causal relationship between the two factor of loss and non-performance of contractual obligations (contractor error). To fulfill contractual liability, it must prove that there is a causal relationship between committed fault (non-performance of contractual obligations) and cause damage; it means that the damage is caused by non-performance of contract. Because it may be possible that committed person do wrong and cause damage to promisee, while damage cause is not his error. The concept of causality as violation of the commitment to damages is realized when it is clear that if the commitment was implemented, damage would not be caused. Thus, if it is realized that even in case of implementation of obligations, agent out of will would cause damage, the offender committed cannot be introduced as liable to compensate the damage, (Shahidi, the same, p.75) thus, the causality is a dependent component from fault. The need for causality violation is obtained from implementation of commitment towards causing damage by Article 521 of the Code of Civil Procedure that the damage caused by the lack of commitment is essential to seek civil damages.

\subsection{Guarantee of Implementation of the Commitments in the Building Contract}

Guarantee of implementation is a power which is used to apply the law or court order; in other words, guarantee of implementation is a direct or indirect means of fulfilling the requirements of law or contract or compensation for losses of injured that this guarantee of implementation is often originated in legal systems or in law or in agreement and contract of committed and the promisee. But those guarantees of implementation which originate in law are such as "the right to compel to perform the same commitment" which can be deduced of materials, $534,426,326,233,232,579$ of the Civil Code. There is a guarantee which legislator considered to implement commitment and can oblige offender of commitment to implement commitment or the powers which the legislator has given to empowered person at different times which according to it, the promisee (empowered) can 
terminate the transaction to prevent increased damage or losses due to deficiency of commitment. In case of non-fulfillment of commitments contemplated by this building contract, the employer can force contractors to implement its commitment.

\subsection{Different Types of Compensation in Iranian Law}

Methods of compensation in civil liability that is the ways of implementing mandate from the performer of damage are based on the aims of civil liability. Since the authenticities of these aims are different in various legal systems, ways of providing them are not the same. These ways are generally as follows: objective compensation and restitution(Safaee and Zakernia, 281-282).

\subsubsection{Objective Compensation}

Objective compensation which sometimes is used as restitution of the injured party's previous status or commodity repair is one of the main ways of compensation in civil liability. Wherever compensation guarantees the restoration of the commodity to its status before the harm had happened; objective compensation happens in physical form. Objective physical compensation includes items such as rejection of the actual property, dispossession of property which has been deforced, reconstruction, elimination of harm source and writing apology and retraction in popular press or recollection of copies of books, videos, CDs and results in the release of condemnation.

\subsubsection{Restitution Compensation}

Compensation through giving the equivalent (similar good or price), is the most common way of compensation to the injured party in civil liability, according to which damage performer must pay the equivalent fine of harmful act to the injured party. In this discussion the restitution will be defined in the first place, and then different types of it will be expressed. In most cases of waste and causality, it is not possible to compensate the actual losses and the only way to compensate the damages to the injured party is paying the equivalent to him. It means that equal to what the injured party has lost must be added to his property and through this his status gets close as much as possible to his previous status. In most legal systems it is paid by money. But sometimes the damage will be compensated by giving its equivalent or other non-cash equivalents (Haji Azizi), therefore paying equivalent is possible in two forms of cash and non-cash.

\section{Construction Contracts according to English Law System}

In this discussion it is tried to study the issues related to compensation in English law system so that compensation method of different damages would be analyzed.

\subsection{Builders of Construction and Buildings' Civil Liability in English Law System}

In English law system, practically the best way to compensate the damage to the injured party is to follow the National House Building Council Scheme (NHBCS) assurance. This guarantee is applied for the constructors and developers of buildings which have been legally registered. The buyers of such houses will get and receive The House Purchaser's Agreement form the seller.

\subsubsection{Liability According to the Subjective Laws of England}

According to the laws of defective buildings which were approved in the house of commons in England in 1922, there has been a limited support for the owners of defective buildings against builders. Paragraph 1, article 1 of this legislation has claimed a triple responsibility for the builders, second handed contractors, architects and other professional performers involved in construction work: a) construction work must be done subtly and masterfully b) proper materials must be used in constructing the buildings c) the constructed house must be appropriate for living.

\subsubsection{Liability According to Carelessness and Recklessness with a Glance on Law Procedures in England}

In 1970s English courts expanded builders' liability on carelessness and recklessness(fault). They considered a responsibility for builders, which must be considered in respect to the injured parties in predictable damages caused by recklessness and carelessness from the builders' side. Since the damage to the owner is an economical damage (contract liability), to solve the problem and to consider the liability as a civil liability they solved the problem in a way that it is a duty that manufacturer has towardthe holder, the responsibility of constructing a building which would not be hazardous to people's health and safety. Since deals in England were economically so unstable, and it was likely that the constructor had exited from the circle of trading building, so there were many lawsuits against municipality which stated that recklessness and carelessness and negligence in approval of the plans and inspections of houses under construction had happen from the part of municipality were established. 


\subsection{Compulsory Compensation Methods in English Law}

In the field of conventional and unconventional civil liability various compensation methods have been expressed which sometimes are applicable instead of each other.

\subsubsection{Ways of Compensating Objective Damage}

Objective compensation which sometimes is used as the restoration of injured party's previous status (Katoozian, 1383 ) is one of the most important ways of compensation in civil liability, in other words the damage must be compensated as if it had not happened (Katoozian, same page, p. 159). This compensation method, is considered the most complete method, whether in compulsory civil liability or in contractual liability. Since the purpose of civil liability is the full compensation of the damage, the above mentioned method which restores victim to his previous statusand damage disappears completely is of priority (Haji Azizi,1380, p.68).

In some legal systems including England, the main effect of civil liability, is damage performer's guarantee for cash compensation of damage, and objective compensation is mainly in a damage which is not arisen from the civil liability. In common law system, the effect is a kind of civil liability to compensate the damage, and in which objective compensation is considered as the financial compensation and prohibited arrangements which primarily is obtained from fair system and in the past only in justice courts was used, but nowadays is also accepted in common law courts (Rogers, 1997, p. 199). In common law, effect is a kind of civil liability to compensate the damage and ask for compensation is the requirement of civil liability (Heuston\&Shambers, 1981, p.8). objective way of compensation or rejection of the actual property and injunction is mainly derived from justice system and in the past was only applied in justice courts, but nowadays it is also accepted in common law courts (Tune, 1971, p. 63). In legal system of England for contracted responsibility, obligation for specific performance is an exceptional compensation and is applied in special conditions (Jone G, 1986. P. 18).

\subsubsection{Restitution Compensation}

Compensation through giving the equivalent (commodity and price), is the most common way of compensation in civil liability according to which damage operator must pay the equivalent of what caused by damage to the injured party. In English law before legal reforms in 1832, giving the equivalent had different forms and after that, unless there was a fiduciary between the parties, it was applied in fewer situations. In some jurisdictions in the U.S giving the equivalent is still sentenced, particularly in situations where complainant's having a property similar to the wasted one is of importance and he cannot acquire it in open market (James, M.F. 2002, p.344).

\subsection{Compensation Methods for Damages Caused by Breach of Contract in English Law}

In English law four types (or models) were predicted for compensating the damages caused by breach of contractual obligations. These four types can be divided into two main groups: in the first group there are some points in which the measure of compensation is the actual damage of the injured party and in the second group the measure for compensation is not damage to the injured party. Compensatory damage is in the first group; and restitution, nominal and punitive are placed in the second group (Rogers, Ibid, p. 177).

\subsubsection{Compensatory Damages}

The aim of Compensatory damage is to compensate the damage to injured party caused by breach of contract. For this reason, compensatory damage is the most important and most common form of reporting damage; hence restitute in integrum or full restitution is the general rule and basis of compensation in English law. One of the results of damages being compensated is that the basis for compensation is the loss to the complainant not the profit that the accused personhas received.

\subsubsection{Restitution Interest}

In this type of damage, prejudicial must refund any profit which has earned as a result of violation of assurance. The basis of restitution interest damage is preventing unjust enrichment of the one who committed violation, not actual harm which happened to oblige (Ibid, 319). This type of damage is usually demanded where the person has signed a contract which ensured damage and unlike the two aforementioned cases the basis for the assessment of damages is not the loss to the promisee, but the profit that promisor earned as a result of breaching the contract. That is for this reason that some authors do not consider restitution interest as criteria for assessing the damage. The common use of restitution interest which clearly illustrates the failure of other compensation in the law of England and inefficiency in the compensation criteria in Iran law is the violation of intellectual property contracts.

\subsubsection{Nominal Damages}

In cases where one of the parties has violated contraction but practically there has been no damage to the 
opposite side, a very small amount of money is sentencedsymbolically for damages. Sentencing this type of damage, is not for compensating the damage of the injured part, but to reflect the ugliness of breaching contract and is of symbolic importance. In symbolic damages, court declaration is the most appropriate type of compensation. Of course, this compensation does not have restoration purpose. In Iranian law unlike English law, considering the principles of compensation since there has been no loss, there is no institution for nominal or symbolic damage. Therefore the mere breach of contract committed by the promisor without prejudicing to promisee does not create any right of compensation. This is for this reason that the "necessity of prejudicing" is among the conditions of compensation in Iran (Katoozian, 1383, p.201).

\subsubsection{Exemplary/Punitive Damages}

Punitive damage does not have restorative effect and are issued to punish the accused person and prevent the perpetration of similar behavior in future. In fact the problem of punitive damage is raised where promisor violates contract in a bold and unconventional way. These types of damages are exceptions to the general rule of restituting damage. Incalculation of this type of damage, both complainant and accused's behavior must be considered and in particular it should considered that how much damage would be enough for punishing the accused person.

\section{Summary and Conclusion}

In conclusion it can be stated that:

Construction contracts are agreements signed between two or more people to carry out any construction activity (in its general term) and the parties promise mutually to work and pay costs of performance.

According to this contract, employer commits contractor's payment, and in return the contractor is committed to the implementation of the contract. In fact, the effects of mandates are limited tomandate itself and because of the validity of these mandates, construction contracts are named covenant contracts. Construction contracts create mandate as soon as they are signed, mandate effect is immediate and does not require time and as soon as it is made, legal effect is applied.

Consent in construction contracts has two elements: subject of contract and price of contract, in which these two elements are placed against each other and therefore construction contracts have commutative properties.

In Iranian law unlike English law on construction contracts there are only general rules. However the structural principles in both Iran and England in the field of civil liability law are somewhat similar and both consider performer of damage responsible, but in Iranian law there is no appropriate separation between occupant, owner and builders' responsibility and general rules are still resorted to. But in English law the injured party must prove the existence of responsibility, which is due to extensive legal regulation is an easy task and if as a result of its violation the responsibility has been affected, the loss is compensable.In Iranian law as soon as causal relationship between damage performer's act of damage and the damage itself is established, the responsibility is proved, but there is no pre-defined task for these people in legal system as it should be.

According to what was stated in this article, in Iranian legal system, compensation methods in construction contracts is implementation to mandate in the first place, and indemnificationis obligatory only if it is explicitly stated in the contract. While in English legal system, means of compensation in construction contracts is indemnification and there is no mandate as a method of compensation. Also in English legal system there is no need to state indemnification explicitly in the contract, while in Iranian legal system indemnification must be explicitly stated in the contract.

\section{References}

CF PADFIELDLLB. (2100). Law made simple, DPA (7th ed.).

Darabpour, M. (1385). civil liability arising from property damage, structures and buildings (comparative study with English law). Journal of Legal Studies, (44).

Hajji Azizi, B. (1380). methods of compensation in civil liability. Daneshvar bimonthly, IX(36).

Heuston, R. F. V. \& Shambers, R. S. (1981). Salmond \& Heuston on the Law of Tort (8th ed.). London.

Hosseini Modares, Seyed Mehdi, Golshani, Esmat. (1392). through compensatory payment of compensation violation of the commitments, a contract in English law and outline it in the law of Iran. Two- Quarterly of civil law, 2(2).

Jackson - Powell(J). (1992). Professional negligence (3rd ed.). London. Sweet \& Maxwell.

James, M. F. (2002). Construction Law (2nd ed.). London, Palgrave. 
Jone, G., \& Goodhart, W. (1986). Specific Performance (1st ed.). London-Butter Worth.

Katouzian, N. (1374). coercive liability and civil liability. Tehran, Tehran University Publications.

Katouzian, N. (1376). general rules of contracts (Vol. 4, 2nd ed.). Tehran, Inc. publication.

Katouzian, N. (1378). specific and complex responsibilities (8th ed.). Tehran University Publications, Tehran.

Katouzian, N. (1383). liability arising from the manufacture fault (2nd ed.). Tehran, Tehran University Publications.

Lawson, F. H. (1980). Remedies of English Law (2nd ed.). London, Butterworths.

Memarian, G. (1386). a review on the theoretical foundations of architecture (2nd ed.). Soroush Publications, Tehran.

Movahedian, G. (1385). labor rights (2nd ed.). Fekrsazan Publications.

Parchami Jalal, M. (1379). Review of the General Conditions of the Old and New treaty, Master thesis in Civil Engineering, Construction Management Engineering, Iran University of Science and Technology.

Qobadian, V. (1387). principles and concepts in contemporary architecture of West (8th ed.). Publishing of Cultural Research Bureau, Tehran.

Rafeie, A. (1392). labor rights (labor legal opinions and legal system governing labor contracts in Iran). Tehran, Negahbineh Publication.

Ranjbari, A. (1377). labor rights. Tehran, Majd publications.

Rogers, W. V. H. (1997). Tort, Seet \& Maxwell (4th ed.). London.

Rubin, H. W., \& Scheil, W. H. (1978). Punitive damage awards the insurance industry in placed on notice. Retrieved from www.heinonline.org

Safai, S. H., \& Zakeri-Nia, H. (1394). comparative analysis of compensation practices in the non-contractual civil liability. Privacy Policy Studies Journal, 45(2).

Shahidi, M. (1380). commitments (1st ed.). Tehran, Majd Publications.

Tune, A. (1971). International Encyclopedia of Comparative Law. London.

\section{Copyrights}

Copyright for this article is retained by the author(s), with first publication rights granted to the journal.

This is an open-access article distributed under the terms and conditions of the Creative Commons Attribution license (http://creativecommons.org/licenses/by/3.0/). 